Jpn. J. Med. Mycol.

Vol. 35, 369-373, 1994

ISSN $0916-4804$

\author{
総説 \\ 真菌症における耐性菌について \\ 一特にアゾール剂耐性菌の現状と問題点一 \\ 内田 勝 久 ${ }^{1)}$ 工 藤 道 誠 ${ }^{1)}$ 渋 谷 和 俊 ${ }^{2)}$ \\ 山 英 世 ${ }^{1)}$ \\ 1) 帝京大学医真菌研究センター \\ 2) 東邦大学医学部大橋病院病理学研究室
}

\begin{abstract}
要旨
近年欧米諸国に扔いて顕性化しつつある酵母様真菌のアゾール剂耐性の問題に関連して，わが国でも 耐性化の傾向がみられるのか否か，耐性菌による感染は実際にアゾール剂の治療に抵抗するのか否か, の二点について基礎的検討を行い, 次のような結果を得た.
\end{abstract}

1. Fluconazole（FLCZ）の上市以前（～1987年12月）と以後（1991年 7 月～1992 年 10 月）に非 AIDS 患者から分離された酵母様真菌 8 菌種, 122 株と 136 株について FLCZ と ketoconazole に対 する in vitro 感受性を測定した結果, 感受性に有意な相違ばなく, 少なくとも 1992 年まではアゾー 儿剂耐性化の傾向は認められなかった。

2. 酵母様真菌臨床分離株の FLCZ 感受性を測定した結果, C. albicans, C. parapsilosis, C. tropicalis 功なる高度感受性菌種群 ( $\mathrm{MIC} \leqq 0.78 \mu \mathrm{g} / \mathrm{ml}$ ), C. guilliermondii, Cr. neoformans, T. cutaneum からなる中等度感受性菌種群 $(1.56 \sim 6.25 \mu \mathrm{g} / \mathrm{ml}), C$. krusei, C. glabrata からな る低感受性菌種群 $(\geqq 25 \mu \mathrm{g} / \mathrm{ml})$ の 3 群に分けられた.

3. マウスの実験的 C. glabrata 致死感染モデルを新たに作成し, C. albicans 感染との比較によっ て攻撃菌の FLCZ 感受性と本剤の治療効果の関係を比較検討した結果，両者の間に高い相関性が認 められた。

Key words：アゾール系薬剤耐性 (Resistance to azole antifungals), 酵母様真菌 (yeast-like fungi), 実験的 C. glabrata 致死感染 (Experimental lethal infections due to C. glabrata)

\section{はじめに}

従来から抗細菌剤の場合と異なり，抗真菌荗で は flucytosine を除けば耐性菌の出現が臨床的に 問題となることはほとんどなかった.しかし近年, AIDS 患者における fluconazole（FLCZ）の長期 治療による耐性 Candida albicans の出現および

別刷請求先 : 内田 勝久

干192-03 東京都八王子市大塚 359

帝京大学医真菌研究センター
低感受性菌 C. krusei や C. glabrataによる症例 の増加の報告が諸外国から相次ぎ，一躍注目され るようになった。

そこでわれわれは，国内でのアゾール剂耐性化 の状況をうかがうために, FLCZの発売が開始さ れた 1989 年より以前の時期（～1987年12月）と以 後の時期（1991年 7 月〜 1992 年 10 月）に収集さ れた酵母様真菌臨床分離株について FLCZ と ketoconazole（KCZ）に対する感受性を比較検討した。 また FLCZ 低感受性菌種であるC. glabrataによ 
るマウスの実験的全身感染モデルを作成し，攻撃 菌の薬剂感受性と治療効果の相関性についても検 討を行った，得られた成績をもとに，現状におけ るアゾール剤耐性の問題点を考察する。

\section{1．文献上にみられるアゾール剤而性菌}

イミダゾール系，トリアゾール系を問わず，一 般にアゾール系薬凨に関しては，通常の治療法を 用いている限り, 耐性獲得や耐性菌出現の問題は ほとんど生じないと考えられる。しかし, 経口ア ゾール剤，とくに FLCZが, AIDS 患者その他の 免疫不全患者を中心に予防的または治療的に，ま すます多用されるようになるにつれて，本来的な 低感受性 (一次耐性) および獲得耐性（二次耐性） の報告が相次ぐようになった。

$\mathrm{KCZ}$ その他のイミダゾール剂に対する二次耐性 化に関しては, Holt \& Azmi ${ }^{11}$ が, 尿路感染症患 者からのC. albicans 分離株が種々のイミダゾール 剤に $100 \mu \mathrm{g} / \mathrm{ml}$ の MIC を示すことを報告したのが 最初である。その後 $\mathrm{KCZ}$ 長期治療を受けた慢性 粘膜皮膚カンジダ症患者から耐性 C. albicans を 分離したという報告が相次いだ2-4)。さらに AIDS 患者からも $\mathrm{KCZ}$ 耐性 C. albicans が分離された ${ }^{5)}$. これらの分離株の多くは KCZのみならず他のイ ミダゾール剤およびトリアゾール剂に対しても交 叉耐性を示すこと，また動物に感染させた場合 $\mathrm{KCZ}$ などのアゾール剤の治療に抵抗すると報告さ れている4,6,7).
一方 FLCZ および itraconazole（ITZ）の耐性 菌に関する確実な報告は, FLCZ 低感受性 $C$. glabrataによる尿路感染の治療中に二次耐性が生 じたという Warnock et al. ${ }^{8)}$ による報告をはじ め, AIDS 患者および外陰腟カンジダ症患者での FLCZ 耐性 C. glabrata の報告がそれぞれ Fox et al. ${ }^{9)}$ およびWhite et al. ${ }^{10)}$ によってなされて いる.C. glabrataは 1 倍体酵母であることから， FLCZ 耐性化をもたらす point mutation が容易 に起こると考えられている. FLCZ 耐性の出現は C. glabrataのみならず, 変異が起こりにくいは ずの 2 倍体酵母 C. albicansにおいても，FLCZ を予防投与または治療中の AIDS 患者に二次耐 性菌が出現したという報告が幾つもみられてい る $^{9,11-15)}$. しかもこれらの耐性株の大多数は, ITZ や KCZ に対し交叉耐性を示すと報告されてい る $10,16,17)$.

\section{2. わが国における臨床分離株のアゾール系薬剤 に対する感受性}

深在性真菌症の起因菌と目される酵母様真菌に ついて, FLCZ 上市前と上市後に分けて, FLCZに 対する感受性を Semisolide-SAAMF 培地による 簡易感受性試験法 ${ }^{18)}$ に従って測定した成績を Table 1 に示す. 用いた菌株は, 1987 年 12 月以前 の分離株 122 株と 1991 年 7 月から 1992 年 10 月に 分離された 136 株である。調べた限り, AIDS 患者 由来の分離株は見当たらない. IC 99 (MIC) 值の

Table 1. In vitro susceptibility to fluconazole (FLCZ) of yeast-like fungal strains freshly isolated from patients, before marketing of FLCZ and afterward

\begin{tabular}{|c|c|c|c|c|}
\hline \multirow{3}{*}{ Species } & \multicolumn{4}{|c|}{$\operatorname{IC} 99(\mu \mathrm{g} / \mathrm{ml})$} \\
\hline & \multicolumn{2}{|c|}{$\sim 1987 / 12$} & \multicolumn{2}{|c|}{$1991 / 7 \sim 1992 / 10$} \\
\hline & $\begin{array}{l}\text { Geometric } \\
\text { mean }\end{array}$ & Range & $\begin{array}{l}\text { Geometric } \\
\text { mean }\end{array}$ & Range \\
\hline Candida albicans & $0.191(64)$ & $\leqq 0.05 \sim 0.78$ & $0.233(63)$ & $\leqq 0.05 \sim 0.78$ \\
\hline Candida parapsilosis & $0.391(8)$ & $0.2 \sim 0.78$ & $0.521(24)$ & $0.1 \sim 1.56$ \\
\hline Candida tropicalis & $0.412(13)$ & $0.2 \sim 1.56$ & $0.391(12)$ & $0.1 \sim 3.13$ \\
\hline Candida glabrata & $11.136(6)$ & $6.25 \sim 12.5$ & $9.364(12)$ & $0.2 \sim 25$ \\
\hline Candida krusei & $15.749(3)$ & $12.5 \sim 25$ & $16.685(12)$ & $0.2 \sim 25$ \\
\hline Candida guilliermondii & $3.125(5)$ & $1.56 \sim 6.25$ & $6.250(2)$ & 6.25 \\
\hline Cryptococcus neoformans & $14.031(18)$ & $6.25 \sim 25$ & $6.252(5)$ & $3.13 \sim 12.5$ \\
\hline Trichosporon cutaneum & $5.441(5)$ & $1.56 \sim 25$ & $4.961(6)$ & $3.13 \sim 6.25$ \\
\hline Total & \multicolumn{2}{|c|}{$\mathrm{n}=122$} & \multicolumn{2}{|c|}{$\mathrm{n}=136$} \\
\hline
\end{tabular}


幾何平均と範囲のどちらで比較しても, FLCZ 上 市前と上市後の間で有意な感受性の低下は認めら れなかった。同じ試験菌株の KCZ 感受性につい ての成績からも耐性菌の出現はみられなかった. したがって非 AIDS 患者においては通常の治療に よってアゾール剤に対する二次耐性菌が出現する ことは，今のところないものと推論された。しか しながらその後，わが国の AIDS 患者からも FLCZ 耐性 C. albicans の分離例が岡ら ${ }^{19)} に よ り$ 報告さ れるに至っている。

今回酵母様真菌 8 菌種の臨床分離株についての FLCZ 感受性試験の成績から，これらの菌種は高 感受性菌種群 ( $\mathrm{MIC} \leqq 0.78 \mu \mathrm{g} / \mathrm{ml}$ ) として $C$. albicans, C. parapsilosis, C. tropicalis, 中等 度感受性菌種群 $(1.56 \sim 6.25 \mu \mathrm{g} / \mathrm{ml})$ として C. guilliermondii, Cr. neoformans, T. cutaneum, さらに低感受性菌種群 $(\geqq 25 \mu \mathrm{g} / \mathrm{ml})$ として $C$. krusei およびC. glabrataの 3 群に分けられた。 したがって一次耐性菌としてとくに注意が必要な のは C. krusei およびC. glabrataの 2 菌種であ ることが確認された。

\section{3. マ マゥスの C. glabrata 全身感染に対する FLCZ の効果}

FLCZ に対して本来的な低感受性すなわち一次 耐性を示す酵母様真菌としてとくにC. kruseiに よる感染症が近年増加傾向にあることが Person et $a l .{ }^{20)}$, Wingard et al. ${ }^{21)}$ により指摘されてい る.さらにAnaissie et $a l .{ }^{22)}$ および Karyotakis et $a l .{ }^{23)}$ は白血球減少症マウスの $C . k r u s e i$ 致死 感染が, FLCZ 治療に抵抗することを示している.

もう一方の一次耐性菌であるC. glabrataに ついては，実験的致死感染モデルに関する報告 はまったく見られない。われわれはマウスに cyclophamide (CY) と prednisolon (PR) の重 複処置を施することにより，致死的感染モデルを 作成することに成功した. CY $200 \mathrm{mg} / \mathrm{kg}$ および PR $30 \mathrm{mg} / \mathrm{kg}$ を前処置したICR 系マウスに臨床 分離株の C. glabrata $1 \times 10^{8}$ 細胞を静脈内接種 した.その後この動物にCY 1 回および PR 2 回 追加投与すると全身感染が成立し菌接種 5 日以内 に全例死亡した. 死亡マウスの病理組織学的検索 から, 腎, 肝を初めとする実質諸臓器において細 胞反応をほとんど伴わない重篤な感染像が認めら
Table 2. Relationship between the effectiveness of fluconazole treatment and the drug sensitivity

\begin{tabular}{ccc}
\hline Test organism & $\begin{array}{c}\mathrm{IC} 99 \\
(\mu \mathrm{g} / \mathrm{ml})\end{array}$ & $\begin{array}{c}\mathrm{ED} 50 \\
(\mathrm{mg} / \mathrm{kg})\end{array}$ \\
\hline C. glabrata TIMM 2849 & 12.5 & 28.0 \\
C. albicans TIMM1768 & 0.39 & 0.62 \\
\hline
\end{tabular}

れた.このC. glabrata 致死感染モデルと従来か ら用いられてきたC. albicans の致死感染モデル を併用し, 試験菌株の FLCZ 感受性（MIC）と治 療効果（ED50）を比較すると, Table 2 に示すよ うに，両者の間に高い相関性がみられた。さらに マウスにおいて測定した FLCZ の血中濃度の成績 24)を当てはめると, C. glabrataの $\mathrm{IC}_{99}$ 值（12.5 $\mu \mathrm{g} / \mathrm{ml})$ は $10 \mathrm{mg} / \mathrm{kg}$ 投与の血中農度 $\left(\mathrm{C}_{\max } 11\right.$ $\mu \mathrm{g} / \mathrm{ml})$ より高濃度であり, 治療効果を表す実測 值の $\mathrm{ED}_{50}(28 \mathrm{mg} / \mathrm{kg})$ とよく対応した. 同様な 関係は C. albicansでも認められた.

これらの感染モデルを用いた治療実験から， FLCZ の in vitro 活性 (MIC) と in vivo 活性 (治療効果) との間には良好な相関関係がみられ ることが示唆される.

\section{おわりに}

媣在性真菌症の発生状況抒よび抗真菌剤の使用 状況からみて, 今後アゾール剤の耐性の問題はさ らに深刻化すると予測される. 現在経ロアゾール 剂による治療が抗真菌化学療法の主流を成してい ること, 現在臨床的に使用されているすべてのア ゾール剤間で交叉耐性がみられることなどを考兄 ると, この耐性の問題の解決は真菌症の治療上大 きな課題である.アゾール剂耐性のメカニズムに ついては, 従来 C. albicans 耐性株を用いた研究 から，エルゴステロール合成系の key enzyme と して知られる $\mathrm{P} 450 \mathrm{DM}$ の薬剂親和性の低下よりむ しろ, 細胞膜の変化による薬剤の細胞内移行の低 下が主因であると推定されてきた ${ }^{25)}$. 最近Vanden Bossche et al. ${ }^{16)}$ は FLCZ 耐性 C. glabrataの生 化学的性状を解析した成績から, (1) FLCZ 取り込 み能の低下, (2)P 450 DM 依存性のエルゴステロー ル合成能の上昇を認めている。また, Hitchcock et al. ${ }^{17)}$ も FLCZ 耐性 C. glabrata 臨床分離株を 用いて検討した結果，耐性は FLCZ 透過性バリア 
の変化に由来すると推論している．われわれも現 在, 実験的に誘導したアゾール剂耐性株および臨 床から新鮮分離された FLCZ 耐性 C. albicans を 用いて種々検討中である。これらの耐性獲得機序 に関する基礎研究の知見に基づいて対策を講ずる とともに, 適切な臨床使用により, 現在かけがえ のない貴重なアゾール系薬剤の臨床的有用性を将 来にわたって保持することが必要である.

謝 辞 : 稿を終わるにあたり，本研究に協力いた だいた(侏)三菱油化ビーシーエル小川哲一氏，手塚 孝一氏, 小林 寅氏, 新鮮臨床分離株を分与いた だいた病院各施設ならびに fluconazole 原末を提 供いただいたファイザー製薬(侏に束心より深謝い たします。

\section{文献}

1) Holt RJ, Azmi A : Miconazole-resistant Candida. Lancet i : 50-51, 1978.

2) Horshurgh $\mathrm{CR}$, Kirkpatrick $\mathrm{CH}$ : Longterm therapy of chronic mucocutaneous candidiasis with ketoconazole: experience with twenty-one patients. Am J Med 74 Suppl 1B : 23-29, 1983.

3) Warnock DW, Johnson EM, Richardson MD, Vickers CFH : Modified response to ketoconazole of Candida albicans from a treatment failure. Lancet i : 642-643, 1983.

4) Smith KJ, Warnock DW, Kennedy CTC, Johnson EM, Hopwood V, Van Cutsem J, Vanden Bossche H: Azole resistance in Candida albicans. J Med Vet Mycol 24: 133-144, 1986.

5) Tavitian A, Raufman J-P, Rosenthal LE, Weber J, Webber CA, Dincsoy HP : Ketoconazole-resistant Candida esophagitis in patients with aquired immunodeficiency syndrome. Gastroenterol $90: 443-445,1986$.

6) Ryley JF, Wilson RG, Barrett-Bee KJ: Azole resistance in Candida albicans. Sabouraudia: J Med Vet Mycol $22: 53-63$, 1984.

7) Johnson EM, Richardson MD, Warnock DW : In-vitro resistance to imidazole antifungals in Candida albicans. J Antimicrob Chemother $13: 547-558,1984$.

8) Warnock DW, Burke J, Cope NJ, Johson EM, von Fraunhofer NA, Wiliams EW :
Fluconazole resistance in Candida glabrata, Lancet ii : 1310, 1988.

9) Fox R, Neal KR, Lee CLS, Ellis ME, Mandal BK: Fluconazole resistant Candida in AIDS. J Infect 22 : 201-204, 1991.

10) White DJ, Johnson EM, Warnock DW: Management of persistent vulvo vaginal candidosis due to azole-resistant Candida glabrata. Genitourin Med 69 : 112-114, 1993.

11) Kitchen VS, Savage M, Harris FRW : Candida albicans resistance in AIDS. J Infect 22 : 201-205, 1991.

12) Smith D, Boag F, Midgley F, Gazzard BG: Fluconazole resistant candida in AIDS. J Infect $23: 345-346,1991$.

13) Willocks L, Lee CLS, Brettle RP, Urequhart D, Russell TB, Milne LJR: Fluconazole resistance in AIDS patients. J Antimicrob Chemother 23 : 937-939, 1991.

14) Dupont B, Gravybill JR, Armstrong D, Laroche R, Touze JE, Wheat LJ : Fungal infections in AIDS patients. $\mathrm{J}$ Med Vet Mycol 29 Suppl : 19-28, 1992.

15) Sanguineti A, Carmichael JK, Campbell $\mathrm{K}$ : Fluconazole-resistant Candida albicans after long-term suppressive therapy. Arch Intern Med 153 : 1122-1124, 1993.

16) Vanden Bossche H, Marichal P, Odds FC, Le Jeune L, Coene M-C: Characterization of an azole-resistant Candida glabrata isolate. Antimicrob Agent Chemother 36 : 2602-2610, 1992.

17) Hitchcock CA, Pye GW, Troke PE, Johnson EM, Warnock DW: Fluconazole resistance in Candida glabrata. Antimicrob Agent Chemother 37 : 1962-1965, 1993.

18）山口英世, 内田勝久, 川崎賢二, 松永敏幸 : トリ アゾール系抗真菌剤 Fluconazole の in vitro 抗 真菌活性. Jap J Antibiotics 42 : 1-16, 1989.

19）岡 慎一: エイズに扔ける真菌感染症例. 真菌誌 34 Suppl 1:69, 1993.

20) Person DA, Laughlin M, Tanner D, Perfect J, Gockerman JP, Hathory JW : Fluconazole and Candida krusei fungemia. New Engl J Med 325 : 1315, 1991.

21) Wingard JR, Merz WG, Rinaldi MG, Johnson TR, Karp JE, Seral R: Increase in Candida krusei infection among patients with bone marrow transplantation and neutropenia treated prophylactically with fluconazole. New Engl J Med $325: 1274^{-}$ 
1277, 1991.

22) Anaissie EJ, Hachem R, K-Tin-U C, Stephens LC, Bodey GP: Experimental hematogenous candidiasis caused by Candida krusei and Candida albicans: species difference in pathogenicity. Infect Immun 61 : 1268-1271, 1993.

23) Karyotakis NC, Anaissie EJ, Hachem R, Dignani MC, Samonis G: Comparison of the efficacy of polyenes and triazoles against hematogenous C. krusei infection in neutropenic mice. $J$ Infect Dis 168 : 1311-1313, 1993.

24）山口英世, 内田勝久: フルコナゾール一基礎. Compromised host と深在性真菌症. p. 8-15, メディカルトリビューン, 1990.

25) Ryley JF, Wilson RG, Barnett-Bee KJ: Azole resistance in Candida albicans. Sabouraudia 22 : 53-63, 1984.

\title{
Antifungal Drug Resistance in Mycosis: The Problem of Azole Resistance
}

\author{
Katsuhisa Uchida ${ }^{1}$, Michinari Kudoh ${ }^{1}$, Kazutoshi Shibuya ${ }^{2}$, Hideyo Yamaguchi ${ }^{1}$ \\ ${ }_{1}^{1}$ Research Center for Medical Mycology, Teikyo University, \\ 359 Otsuka, Hachioji, Tokyo 192-03 \\ 2 Department of Pathology, Ohashi Hospital, Toho University School of Medicine, \\ 2-17-6, Ohashi, Meguro, Tokyo 153
}

The emergence of Candida albicans resistant to fluconazole (FLCZ) because of long-term treatment in AIDS patients and the increase of infections with C. krusei and C. glabrata poorly sensitive to FLCZ have attracted attention in other countries. This study examined the possibility of a tendency toward azole-resistance among fungal isolates in Japan and the effect of antifungal agent treatment of infections by resistant fungi. The following results were obtained:

1. The sensitivity to FLCZ and ketoconazole was determined on eight species of yeast-like fungi, including 122 strains isolated before marketing of FLCZ (up to December 1987) and 138 strains isolated afterward (July 1991 to October 1992). No significant differences in sensitivity were detected, which suggests the absence of a tendency toward azole resistance among the fungal strains.

2. Among the clinical isolates tested, C. albicans, C. parapsilosis and C. tropicalis were highly sensitive to FLCZ ( $\mathrm{IC}_{99} \leqq 0.78 \mu \mathrm{g} / \mathrm{ml}$ ), C. guilliermondii, Cr. neoformans and T. cutaneum were moderately sensitive $(1.56$ to $6.25 \mu \mathrm{g} / \mathrm{ml}$ ) and $C$. krusei and C. glabrata were poorly sensitive (up to $25 \mu \mathrm{g} / \mathrm{ml}$ ).

3. An experimental model of lethal C. glabrata infection in mice was established. Using this model and comparing it with $C$. albicans infection, the relationship between the effectiveness of FLCZ treatment and the drug sensitivity of the challenged fungi to FLCZ were examined. A good correlation was obtained depending on the serum drug level.

\footnotetext{
この論文は, 第 37 回日本医真菌学会総会の “ワークショップ: 2. 抗真菌

療法の進歩と問題点”に打いて発表されたものです。
} 